\title{
Characterization and Cytotoxicity Assessment of the Lipophilic Fractions of Different Morphological Parts of Acacia dealbata
}

\author{
Cátia S. D. Oliveira ${ }^{1}$, Patrícia Moreira ${ }^{2}{ }^{-}$, Judite Resende ${ }^{1,3}{ }^{\oplus}$, Maria T. Cruz ${ }^{2,4}$, \\ Cláudia M. F. Pereira ${ }^{2,5} \mathbb{D}^{-}$, Artur M. S. Silva ${ }^{3} \mathbb{D}$, Sónia A. O. Santos ${ }^{1} \mathbb{D}$ and \\ Armando J. D. Silvestre ${ }^{1, * \mathbb{D}}$ \\ 1 CICECO-Aveiro Institute of Materials, University of Aveiro, 3810-193 Aveiro, Portugal; \\ cs.oliveira@ua.pt (C.S.D.O.); judite.resende@ua.pt (J.R.); santos.sonia@ua.pt (S.A.O.S.) \\ 2 CNC - Center for Neuroscience and Cellular Biology, University of Coimbra, 3004-504 Coimbra, Portugal; \\ patriciaraquel_jm@hotmail.com (P.M.); trosete@ff.uc.pt (M.T.C.); claudia.mf.pereira@gmail.com (C.M.F.P.) \\ 3 LAQV-REQUIMTE, Department of Chemistry, University of Aveiro, 3810-193 Aveiro, Portugal; \\ artur.silva@ua.pt \\ 4 Faculty of Pharmacy, University of Coimbra, 3000-548 Coimbra, Portugal \\ 5 Faculty of Medicine, University of Coimbra, 3000-548 Coimbra, Portugal \\ * Correspondence: armsil@ua.pt
}

Received: 10 February 2020; Accepted: 3 March 2020; Published: 6 March 2020

\begin{abstract}
Acacia dealbata biomass, either from forest exploitation or from the management of invasive species, can be a strategic topic, namely as a source of high-value compounds. In this sense, the present study aimed at the detailed characterization of the lipophilic components of different morphological parts of $A$. dealbata and the evaluation of their cytotoxicity in cells representative of different mammals tissues. The chemical composition of lipophilic extracts from $A$. dealbata bark, wood and leaves was evaluated using gas chromatography-mass spectrometry (GC-MS). Terpenic compounds (representing $50.2 \%-68.4 \%$ of the total bark and leaves extracts, respectively) and sterols (60.5\% of the total wood extract) were the main components of these extracts. Other constituents, such as fatty acids, long-chain aliphatic alcohols, monoglycerides, and aromatic compounds were also detected in the studied extracts. All the extracts showed low or no cytotoxicity in the different cells tested, demonstrating their safety profile and highlighting their potential to be used in nutraceutical or pharmaceutical applications. This study is therefore an important contribution to the valorization of $A$. dealbata, demonstrating the potential of this species as a source of high value lipophilic compounds.
\end{abstract}

Keywords: Acacia dealbata; forest biomass; biorefinery; lipophilic compounds; GC-MS analysis; cytotoxicity; nutraceutical applications; pharmaceutical applications

\section{Introduction}

Acacia dealbata (silver wattle or mimosa) is a woody legume, introduced in Europe in the 18th century, which then invaded Atlantic and Mediterranean climates, from Portugal to Italy [1-4]. Soil disturbances, fires, and climate changes, leading to increasing areas susceptible to colonization [3] have probably contributed to A. dealbata invasion of many regions. Although this species produces wood suitable for good quality pulp fibers [5-7], its industrial applications have been mainly focused on wood for furniture [8], gum, or as a substitute of gum arabic, on bark for tanning production [7,9-11], and on flowers for absolute oil production, and in the flavor and perfumes industry [12]. In addition, A. dealbata has been traditionally used to control soil erosion, and as an ornamental species [13]. 
Notwithstanding, the invading behavior of $A$. dealbata turned it into a major concern for the forestry sector, particularly for the pulp and paper industry and the respective Eucalyptus species plantations [14]. Actually, A. dealbata has been considered a residue for pulp industry, being left in the forest or used essentially an energy source $[9,15,16]$. Thus, the valorization of this species for high value applications is of major importance for countries where pulp and paper industry has a high impact. In fact, this industry is increasingly on the alert for waste reduction and recovery of residual forest biomass.

So far, only a few studies have been focused on searching innovative ways to add value to A. dealbata, demonstrating that it is particularly interesting as a source of high-value compounds $[8,15,17]$. Nevertheless, these studies have only focused on specific families [8,15], specific tree parts [17], or even neglected the quantification of the compounds detected [8]. In fact, while different phytosterols were identified and quantified in A. dealbata wood and bark [15], only two terpenic compounds were reported as constituents of this species, namely lupenone in leaves, flowers and seeds and lupeol in leaves [8], and in both cases without quantitative data. Some fatty acids, long-chain aliphatic alcohols, and monoglycerides were also identified in A. dealbata bark [17], but their presence in other parts of the tree as well as their abundance remain unknown.

Additionally, the cytotoxicity of $A$. dealbata lipophilic extracts has not been exploited so far, although a wide range of biological properties have been already reported for some of its constituents, such as the anti-inflammatory, antidiabetic, antiviral, and anticancer activities of lupenone [18] and anti-inflammatory, antiproliferative, and anticarcinogenic activities associated to spinasterol and 22,23-dihydrospinasterol [19-22], which were identified as the major sterols in A. dealbata bark and wood [15].

In this vein, the detailed knowledge about the lipophilic composition of different morphological parts of $A$. dealbata, envisaging their integrated exploitation, remains scarce, particularly concerning all the important families of lipophilic compounds, like fatty acids, long-chain aliphatic alcohols, sterols, terpenic compounds, or monoglycerides.

In order to fill this gap, this work aims at a systematic study concerning the lipophilic composition of the bark, wood, and leaves of $A$. dealbata, by gas chromatography-mass spectrometry analysis (GC-MS). Additionally, and in order to evaluate the potential exploitation of $A$. dealbata lipophilic fractions for pharmaceutical (in oral or topical applications) and nutraceutical purposes, the cytotoxicity in different cell lines representative of different tissues and organs, such as the brain, innate immune system, skin, lung, and liver is also disclosed.

\section{Results and Discussion}

\subsection{Lipophilic Extractives Yield of A. dealbata Bark, Wood and Leaves}

The dichloromethane extracts from $A$. dealbata bark, wood and leaves presented distinct extraction yields. A. dealbata leaves showed the highest yield, accounting for $6.2 \pm 0.22 \%$, followed by bark extract $(2.3 \pm 0.25 \%)$, while wood presented the lowest yield, accounting for $0.30 \pm 0.01 \%$.

The extraction yields obtained for $A$. dealbata bark and wood are in accordance with those already reported in the literature for these morphological parts (2.00 \pm 0.06 and $0.36 \pm 0.03 \%$, respectively) [15]. Although no data have been reported so far concerning the lipophilic extraction yield of $A$. dealbata leaves, the value obtained is higher than that reported for the hexane extract of $A$. sinulata leaves [23].

\subsection{Chemical Characterization of the Lipophilic Extract}

The chemical composition of the dichloromethane extracts of the three morphological parts of A. dealbata was studied by GC-MS analysis. Six main families of lipophilic compounds were identified and quantified, namely fatty acids, long-chain aliphatic alcohols (LCAAs), terpenic compounds, sterols, monoglycerides and aromatic compounds (Figure 1). The identification and detailed quantification of the main lipophilic components are summarized in Table 1 . The total contents of identified compounds were $976.3 \mathrm{mg} \mathrm{kg}^{-1} \mathrm{dw}$ in wood, $6872.4 \mathrm{mg} \mathrm{kg}^{-1} \mathrm{dw}$ in bark, and $21394.5 \mathrm{mg} \mathrm{kg}^{-1} \mathrm{dw}$ in leaves. 




Figure 1. The major families of lipophilic compounds identified in DCM extracts of $A$. dealbata bark, wood and leaves. Abbreviations: FA, fatty acids; LCAA, long-chain aliphatic alcohols; T, terpenic compounds; ST, sterols; MG, monoglycerides and AR, aromatic compounds.

Table 1. Chemical composition of dichloromethane extracts from bark, wood and leaves lipophilic of A. dealbata.

\begin{tabular}{|c|c|c|c|c|c|c|c|}
\hline \multirow[t]{2}{*}{$\mathbf{R} \mathbf{t}_{(\min )}$} & \multirow[t]{2}{*}{ Compound } & \multicolumn{3}{|c|}{$\mathrm{mg} \mathrm{g}^{-1}$ of Extract } & \multicolumn{3}{|c|}{$\mathrm{mg} \mathrm{kg}^{-1}$ of dw } \\
\hline & & Bark & Wood & Leaves & Bark & Wood & Leaves \\
\hline & Fatty acids & 46.2 & 95.1 & 28.3 & 1060.0 & 290.0 & 1747.4 \\
\hline & Saturated fatty acids & 41.2 & 55.4 & 23.0 & 946.1 & 168.7 & 1415.9 \\
\hline 24.12 & Dodecanoic acid & 0.1 & 0.3 & 0.2 & 2.9 & 0.9 & 12.9 \\
\hline 29.26 & Tetradecanoic acid & 0.1 & 0.3 & 0.4 & 2.7 & 0.9 & 24.0 \\
\hline 31.65 & Pentadecanoic acid & 0.1 & 0.5 & n.d. & 1.7 & 1.4 & n.d. \\
\hline 33.95 & Hexadecanoic acid & 5.4 & 22.9 & 6.3 & 124.3 & 69.7 & 389.1 \\
\hline 36.15 & Heptadecanoic acid & 0.1 & 1.1 & 0.1 & 3.0 & 3.3 & 7.2 \\
\hline 38.26 & Octadecanoic acid & 0.8 & 8.4 & 1.0 & 17.4 & 25.6 & 59.4 \\
\hline 40.28 & Nonadecanoic acid & 0.1 & 0.6 & n.d. & 1.4 & 1.7 & n.d. \\
\hline 42.25 & Eicosanoic acid & 0.4 & 2.3 & 0.7 & 8.4 & 6.9 & 41.5 \\
\hline 44.14 & Heneicosanoic acid & 0.2 & 1.6 & 0.3 & 3.5 & 5.0 & 21.4 \\
\hline 45.96 & Docosanoic acid & 1.6 & 4.6 & 0.9 & 36.5 & 14.1 & 55.1 \\
\hline 47.73 & Tricosanoic acid & 0.5 & 2.8 & 0.6 & 12.6 & 8.5 & 37.2 \\
\hline 49.43 & Tetracosanoic acid & 6.1 & 6.2 & 1.3 & 141.0 & 18.8 & 80.0 \\
\hline 51.10 & Pentacosanoic acid & 0.6 & 1.7 & n.d. & 13.9 & 5.1 & n.d. \\
\hline 52.90 & Hexacosanoic acid & 3.7 & 2.2 & 1.4 & 85.9 & 6.6 & 86.3 \\
\hline 54.80 & Heptacosanoic acid & 1.1 & n.d. & n.d. & 24.5 & n.d. & n.d. \\
\hline 56.83 & Octacosanoic acid & 5.3 & n.d. & 5.4 & 120.5 & n.d. & 334.1 \\
\hline 58.87 & Nonacosanoic acid & 3.1 & n.d. & n.d. & 72.0 & n.d. & n.d. \\
\hline 61.10 & Triacontanoic acid & 8.2 & n.d. & 4.3 & 188.9 & n.d. & 267.5 \\
\hline \multirow[t]{2}{*}{65.98} & Dotriacontanoic acid & 3.7 & n.d. & n.d. & 84.9 & n.d. & n.d. \\
\hline & Unsaturated fatty acids & 4.2 & 38.7 & 5.4 & 95.7 & 118.0 & 331.5 \\
\hline 33.34 & Hexadec-9-enoic acid & 0.1 & 0.2 & 0.1 & 1.3 & 0.7 & 6.1 \\
\hline
\end{tabular}


Table 1. Cont.

\begin{tabular}{|c|c|c|c|c|c|c|c|}
\hline \multirow[t]{2}{*}{$\mathbf{R t}_{(\min )}$} & \multirow[t]{2}{*}{ Compound } & \multicolumn{3}{|c|}{$\mathrm{mg} \mathrm{g}^{-1}$ of Extract } & \multicolumn{3}{|c|}{$\mathrm{mg} \mathrm{kg}^{-1}$ of dw } \\
\hline & & Bark & Wood & Leaves & Bark & Wood & Leaves \\
\hline 37.38 & Octadeca-9,12-dienoic acid & 1.7 & 31.9 & 1.7 & 39.6 & 97.2 & 104.4 \\
\hline 37.42 & Octadeca-9,12,15-trienoic acid & 0.4 & 1.2 & 1.9 & 9.4 & 3.7 & 116.2 \\
\hline 37.58 & cis-Octadec-9-enoic acid & 1.6 & 4.1 & 1.5 & 36.3 & 12.6 & 89.6 \\
\hline \multirow[t]{2}{*}{37.73} & trans-Octadec-9-enoic acid & 0.4 & 1.3 & 0.2 & 9.2 & 3.8 & 15.1 \\
\hline & $w$-Hydroxyacids & 0.8 & 1.1 & n.d & 18.2 & 3.3 & n.d. \\
\hline \multirow[t]{2}{*}{52.01} & 22-Hydroxydocosanoic & 0.8 & 1.1 & n.d. & 18.2 & 3.3 & n.d. \\
\hline & Long-chain aliphatic alcohols & 47.2 & 14.2 & 30.7 & 1082.5 & 43.7 & 1891.5 \\
\hline 22.02 & Dodecan-1-ol & 0.01 & 0.5 & 0.02 & 0.3 & 1.4 & 1.4 \\
\hline 24.73 & Tridecan-1-ol & 0.1 & 1.4 & 0.05 & 1.2 & 4.2 & 3.1 \\
\hline 27.35 & Tetradecan-1-ol & 0.04 & 2.2 & n.d. & 0.9 & 6.8 & n.d. \\
\hline 29.85 & Pentadecan-1-ol & 0.7 & 2.0 & n.d. & 15.9 & 6.2 & n.d. \\
\hline 32.19 & Hexadecan-1-ol & 0.04 & 0.6 & 0.1 & 0.8 & 1.8 & 8.1 \\
\hline 36.63 & Octadecan-1-ol & 0.1 & 0.4 & 0.1 & 2.0 & 1.4 & 3.1 \\
\hline 40.71 & Eicosan-1-ol & 0.1 & n.d. & n.d. & 2.0 & n.d. & n.d. \\
\hline 44.50 & Docosan-1-ol & 0.2 & 0.3 & n.d. & 4.3 & 1.2 & n.d. \\
\hline 46.30 & Tricosan-1-ol & 0.2 & n.d. & n.d. & 3.7 & n.d. & n.d. \\
\hline 48.05 & Tetracosan-1-ol & 3.8 & n.d. & n.d. & 86.5 & n.d. & n.d. \\
\hline 49.73 & Pentacosan-1-ol & 0.9 & n.d. & n.d. & 19.8 & n.d. & n.d. \\
\hline 51.43 & Hexacosan-1-ol & 11.6 & n.d. & 3.0 & 265.5 & n.d. & 184.1 \\
\hline 53.21 & Heptacosan-1-ol & 1.5 & n.d. & n.d. & 34.3 & n.d. & n.d. \\
\hline 55.15 & Octacosan-1-ol & 9.6 & 1.8 & 4.2 & 221.0 & 5.6 & 261.0 \\
\hline 57.17 & Nonacosan-1-ol & 2.3 & n.d. & n.d. & 53.2 & n.d. & n.d. \\
\hline 59.25 & Triacontan-1-ol & 10.8 & 5.0 & 16.8 & 247.9 & 15.2 & 1035.2 \\
\hline \multirow[t]{2}{*}{63.71} & Dotricontan-1-ol & 5.4 & n.d. & 6.4 & 123.3 & n.d. & 395.6 \\
\hline & Terpenic compounds & 150.5 & n.d. & 237.4 & 3450.8 & n.d. & $14,635.3$ \\
\hline 29.00 & Neophytadiene & n.d. & n.d. & 2.6 & n.d. & n.d. & 158.8 \\
\hline 37.02 & Phytol & n.d. & n.d. & 5.5 & n.d. & n.d. & 340.6 \\
\hline 48.89 & Squalene & n.d. & n.d. & 28.4 & n.d. & n.d. & 1747.6 \\
\hline 56.66 & $\beta$-Amyrone & n.d. & n.d. & 20.4 & n.d. & n.d. & 1256.5 \\
\hline 57.57 & Lupenone & 56.4 & n.d. & 112.7 & 1293.7 & n.d. & 6946.8 \\
\hline 58.36 & $\beta$-Amyrin & n.d. & n.d. & 26.1 & n.d. & n.d. & 1606.8 \\
\hline 58.97 & $\alpha$-Amyrin & n.d. & n.d. & 41.8 & n.d. & n.d. & 2578.2 \\
\hline \multirow[t]{2}{*}{60.52} & Lupenyl acetate & 94.0 & n.d. & n.d. & 2157.1 & n.d. & n.d. \\
\hline & Sterols & 21.1 & 193.7 & 10.3 & 484.2 & 590.4 & 635.7 \\
\hline 58.39 & Spinasterol & 8.6 & 94.6 & n.d. & 198.3 & 288.5 & n.d. \\
\hline 58.69 & Sitostanol & n.d. & 7.0 & n.d. & n.d. & 21.2 & n.d. \\
\hline \multirow[t]{2}{*}{59.63} & 22,23-Dihydrospinasterol & 12.5 & 92.1 & 10.3 & 285.8 & 280.7 & 635.7 \\
\hline & Monoglycerides & 30.2 & 6.0 & 0.8 & 691.6 & 18.4 & 49.4 \\
\hline 45.14 & 1-Monohexadecenoin & n.d. & n.d. & 0.3 & n.d. & n.d. & 16.7 \\
\hline 45.36 & 1-Monohexadecanoin & 0.1 & 2.8 & 0.5 & 3.4 & 8.4 & 32.7 \\
\hline 47.55 & 2-Monolinolein & n.d. & 0.5 & n.d. & n.d. & 1.6 & n.d. \\
\hline 48.13 & 1-Monolinolein & n.d. & 2.8 & n.d. & n.d. & 8.4 & n.d. \\
\hline 55.92 & 1-Monodocosanoin & 6.5 & n.d. & n.d. & 149.5 & n.d. & n.d. \\
\hline \multirow[t]{3}{*}{60.06} & 1-Monotetracosanoin & 23.5 & n.d. & n.d. & 538.7 & n.d. & n.d. \\
\hline & Aromatic compounds & 1.3 & 8.8 & 1.8 & 29.0 & 26.9 & 112.0 \\
\hline & Aromatic aldehydes & 0.2 & 5.8 & 0.1 & 4.4 & 17.6 & 9.1 \\
\hline 14.86 & 4-Hydroxybenzaldehyde & 0.1 & 0.3 & 0.1 & 1.3 & 0.8 & 7.3 \\
\hline 19.75 & Vanillin & 0.1 & 2.2 & n.d. & 2.5 & 6.8 & n.d. \\
\hline 24.42 & Syringaldehyde & 0.02 & 1.4 & 0.03 & 0.6 & 4.2 & 1.8 \\
\hline 24.53 & 2,5-Hydroxybenzaldehyde & n.d. & 0.8 & n.d. & n.d. & 2.5 & n.d. \\
\hline 28.02 & Coniferaldehyde & n.d. & 0.5 & n.d. & n.d. & 1.5 & n.d. \\
\hline
\end{tabular}


Table 1. Cont.

\begin{tabular}{|c|c|c|c|c|c|c|c|}
\hline \multirow[t]{2}{*}{$\mathbf{R} \mathbf{t}_{(\min )}$} & \multirow[t]{2}{*}{ Compound } & \multicolumn{3}{|c|}{$\mathrm{mg} \mathrm{g}^{-1}$ of Extract } & \multicolumn{3}{|c|}{$\mathrm{mg} \mathrm{kg}^{-1}$ of dw } \\
\hline & & Bark & Wood & Leaves & Bark & Wood & Leaves \\
\hline \multirow[t]{2}{*}{31.89} & Sinapaldehyde & n.d. & 0.6 & n.d. & n.d. & 1.8 & n.d. \\
\hline & Aromatic acids & 0.7 & 2.1 & 0.8 & 15.9 & 6.4 & 47.7 \\
\hline 10.98 & Benzoic acid & n.d. & n.d. & 0.1 & n.d. & n.d. & 7.0 \\
\hline 23.24 & $p$-Hydroxybenzoic acid & 0.1 & 0.04 & 0.1 & 1.3 & 0.1 & 8.4 \\
\hline 26.85 & Vanillic acid & 0.2 & 1.2 & 0.2 & 5.6 & 3.8 & 12.4 \\
\hline 26.97 & Homovanillic acid & 0.1 & 0.1 & n.d. & 1.2 & 0.3 & n.d. \\
\hline 30.18 & Syringic acid & 0.3 & 0.7 & n.d. & 7.8 & 2.2 & n.d. \\
\hline \multirow[t]{2}{*}{31.09} & $p$-Coumaric acid & n.d. & n.d. & 0.3 & n.d. & n.d. & 19.8 \\
\hline & Other aromatic compounds & 0.4 & 1.0 & 0.9 & 8.8 & 2.9 & 55.3 \\
\hline 16.07 & Resorcinol & 0.1 & n.d. & 0.1 & 2.8 & n.d. & 6.8 \\
\hline 21.75 & Tyrosol & 0.02 & 0.1 & 0.8 & 0.5 & 0.3 & 48.5 \\
\hline 23.62 & Vanillyl alcohol & 0.2 & 0.4 & n.d. & 5.5 & 1.2 & n.d. \\
\hline \multirow[t]{2}{*}{27.76} & p-Coumaric alcohol & n.d. & 0.5 & n.d. & n.d. & 1.4 & n.d. \\
\hline & Others & 3.2 & 2.3 & 37.7 & 74.4 & 6.9 & 2323.2 \\
\hline 13.44 & Glycerol & 0.9 & 1.5 & 5.5 & 20.2 & 4.6 & 339.7 \\
\hline 15.57 & $\begin{array}{l}\text { trans-Erythronoic } \\
\text { acid- } \gamma \text {-lactone }\end{array}$ & 0.2 & 0.5 & 0.4 & 4.2 & 1.6 & 21.6 \\
\hline 17.01 & cis-Erythronoic acid- $\gamma$-lactone & 0.2 & 0.2 & 0.4 & 3.8 & 0.7 & 25.7 \\
\hline \multirow[t]{2}{*}{54.54} & $\alpha$-Tocopherol & 2.0 & n.d. & 31.4 & 46.1 & n.d. & 1936.1 \\
\hline & Total & 299.6 & 320.2 & 347.1 & 6872.4 & 976.3 & $21,394.5$ \\
\hline
\end{tabular}

Terpenic compounds were the main family present in the bark and leaves extracts, with contents ranging from $3450.8 \mathrm{mg} \mathrm{kg}^{-1} \mathrm{dw}$ in bark to $14,635.3 \mathrm{mg} \mathrm{kg}^{-1} \mathrm{dw}$ in leaves (representing $50.2 \%$ and $68.4 \%$ of the total content of identified compounds in bark and leaves, respectively). In opposition, terpenic compounds were not found in the wood extract. Actually, the lipophilic extract of this morphological part was shown to be mainly composed of sterols, with a content of $590.4 \mathrm{mg} \mathrm{kg}^{-1} \mathrm{dw}$, representing $60.5 \%$ of the total content of identified compounds in wood.

\subsubsection{Fatty Acids}

Fatty acids represent between $8.2 \%$ (leaves) and $29.7 \%$ (wood) of the total lipophilic components extracted from the different morphological parts of $A$. dealbata. Total saturated fatty acids accounted for $168.7 \mathrm{mg} \mathrm{kg}^{-1} \mathrm{dw}$ in wood, $946.1 \mathrm{mg} \mathrm{kg}^{-1} \mathrm{dw}$ in bark and $1415.9 \mathrm{mg} \mathrm{kg}^{-1} \mathrm{dw}$ in leaves. Saturated fatty acids were found at higher contents than unsaturated ones, accounting for $81.0 \%$ and $89.3 \%$ of the total fatty acids content in leaves and bark, respectively. The chain length of fatty acids ranged from 12 to 32 carbon atoms. Hexadecanoic acid was the most abundant saturated fatty acid found in leaves and wood, accounting for 389.1 and $69.7 \mathrm{mg} \mathrm{kg}^{-1} \mathrm{dw}$, respectively, whereas triacontanoic acid was the most abundant saturated fatty acid in bark, accounting for $188.9 \mathrm{mg} \mathrm{kg}^{-1} \mathrm{dw}$.

Considerable amounts of unsaturated fatty acids were found in bark, wood and leaves, with contents ranging from 95.7 to $331.5 \mathrm{mg} \mathrm{kg}^{-1} \mathrm{dw}$. These components represented about $40.7 \%$ of the total fatty acids detected in wood, accounting $118.0 \mathrm{mg} \mathrm{kg}^{-1} \mathrm{dw}$. Octadeca-9,12-dienoic acid, an $\omega-6$ fatty acid, was the most abundant unsaturated fatty acid detected in bark and wood, accounting for, respectively 39.6 and $97.2 \mathrm{mg} \mathrm{kg}^{-1} \mathrm{dw}$, while the $\omega-3$ fatty acid octadeca-9,12,15-trienoic acid was the major unsaturated fatty acid observed in leaves, accounting for $116.2 \mathrm{mg} \mathrm{kg}^{-1} \mathrm{dw}$.

Unsaturated acids, despite being essential for human health, are not synthesized by the body. These compounds are associated with the prevention and/or treatment of chronic and acute diseases such as cardiovascular disease, cancer, osteoporosis and immune disorders [24]. Their abundance in A. dealbata lipophilic extracts thus highlights the potential of this fraction to be exploited in nutraceutical applications. 
So far, only a limited number of fatty acids were identified in A. dealbata, and particularly in the bark, namely hexadecenoic, octadeca-9,12-dienoic, docosanoic, tetracosanoic, octacosanoic and triacontanoic acids [17]. All the remaining fatty acids were identified here for the first time as bark constituents. In addition, fatty acids identified in wood and leaves are reported here for the first time.

\subsubsection{Long-Chain Aliphatic Alcohols}

Long-chain aliphatic alcohols (LCAA) were also detected in all extracts and represented a significative fraction of the total content of identified lipophilic compounds. The highest LCAA contents were found in leaves and bark (1891.5 and $1082.5 \mathrm{mg} \mathrm{kg}^{-1} \mathrm{dw}$, respectively), while a considerably lower amount was observed in wood $\left(43.7 \mathrm{mg} \mathrm{kg}^{-1} \mathrm{dw}\right)$. Triacontan-1-ol was the major LCAA in wood and leaves, with contents of $15.2 \mathrm{mg} \mathrm{kg}^{-1} \mathrm{dw}$ and $1035.2 \mathrm{mg} \mathrm{kg}^{-1} \mathrm{dw}$, respectively. The bark extract showed the highest number of LCAA, presenting chain lengths from 12 to 32 carbon atoms. Hexacosan-1-ol was the most abundant LCAA in this morphological part, reaching up to $265.5 \mathrm{mg} \mathrm{kg}^{-1} \mathrm{dw}$. Although no information has been reported so far regarding the LCAA content in the different morphological parts of this tree, it was suggested in a previous study [17] that hexacosan-1-ol was the major LCAA of $A$. dealbata bark DCM extract, which is in accordance with the findings of the present study.

With the exception of tetracosan-1-ol, hexacosan-1-ol, octacosan-1-ol and triacontan-1-ol, which were previously identified in A. dealbata bark [17], all the other LCAA (Table 1) are reported here for the first time in this morphological part. Considering wood and leaves fractions, to the best of our knowledge, this is the first study reporting the LCAA profile in these morphological parts of A. dealbata.

\subsubsection{Terpenic Compounds}

Terpenic compounds were the main family identified in bark and leaves lipophilic extracts, accounting for about $50.2 \%$ and $68.4 \%$ of the total content of identified lipophilic compounds, respectively (Figure 1). Terpenic compounds were absent in the wood extract, while two triterpenic compounds were found in the bark lipophilic extract in relatively high amounts, namely lupenone (1293.7 $\mathrm{mg} \mathrm{kg}^{-1} \mathrm{dw}$ ) and lupenyl acetate (2157.1 $\mathrm{mg} \mathrm{kg}^{-1} \mathrm{dw}$ ) (Figure 2). Interestingly, this component was only present in the bark extract. Seven terpenic compounds were identified in the leaves extract, corresponding to a total content of $14,635.3 \mathrm{mg} \mathrm{kg}^{-1} \mathrm{dw}$. Among those, lupenone was the most abundant compound of this family in leaves $\left(6946.8 \mathrm{mg} \mathrm{kg}^{-1} \mathrm{dw}\right)$, followed by $\alpha$-amyrin $\left(2578.2 \mathrm{mg} \mathrm{kg}^{-1} \mathrm{dw}\right)$ and squalene (1747.6 $\mathrm{mg} \mathrm{kg}^{-1} \mathrm{dw}$ ). From the identified terpenic compounds, only lupenone has been previously reported as constituent of $A$. dealbata leaves [8].

Plant-derived triterpenic compounds have been associated with a wide variety of biological activities. Lupenone, present in bark and leaves extracts (56.4 and $112.7 \mathrm{mg} \mathrm{g}^{-1}$ extract, respectively), has been described as a potential therapeutic agent in inflammation, diabetes, virus infection, cancer and Chagas disease [18]. Lupenyl acetate, identified in the bark extract ( $94.0 \mathrm{mg} \mathrm{g}^{-1}$ extract), has been reported to possess in vitro and in vivo anti-inflammatory activity $[25,26]$, highlighting the potential of $A$. dealbata lipophilic fraction for high value applications. 
<smiles></smiles>

Lupenone

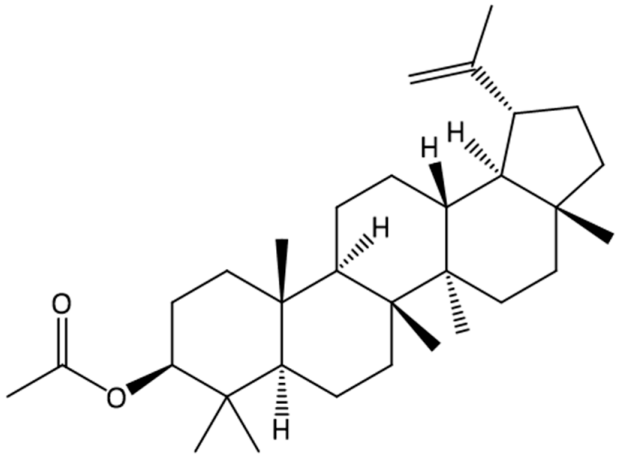

Lupeol acetate

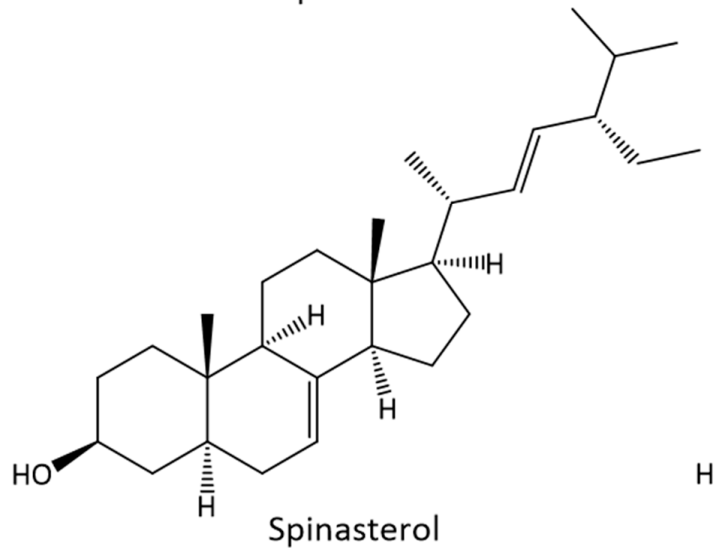<smiles>CC[C@H](CC[C@@H](C)[C@H]1CC[C@H]2C3=CCC4C[C@@H](O)CC[C@]4(C)[C@H]3CC[C@@]21C)C(C)C</smiles>

22,23-Dihydrospinasterol

Figure 2. Chemical structures of the major constituents identified in the A. dealbata bark, wood and leaves lipophilic extracts.

\subsubsection{Sterols}

Considerable amounts of sterols were observed in the three morphological parts of A. dealbata, with contents ranging from $484.2 \mathrm{mg} \mathrm{kg}^{-1} \mathrm{dw}$ in bark to $635.7 \mathrm{mg} \mathrm{kg}^{-1} \mathrm{dw}$ in leaves. Wood extract showed to be particularly rich in sterols (Figure 1), with this family representing $60.5 \%$ of the total compounds identified. Two $\Delta^{7}$ sterols were identified in bark and wood, namely 22,23-dihydrospinasterol (285.8 and 280.7 and $\mathrm{mg} \mathrm{kg}^{-1} \mathrm{dw}$, respectively) and spinasterol (198.3 and 288.5 and $\mathrm{mg} \mathrm{kg}^{-1} \mathrm{dw}$, respectively) (Figure 2). In addition, sitostanol was also identified in wood, accounting for $21.2 \mathrm{mg} \mathrm{kg}^{-1} \mathrm{dw}$.

From a qualitative point of view, the sterols identified in bark and wood are in accordance with previous reports [15]. However, some differences can be pointed out from a quantitative perspective. Actually, sterols contents observed for bark and wood $\left(484.2\right.$ and $590.4 \mathrm{mg} \mathrm{kg}^{-1} \mathrm{dw}$, respectively) were considerably higher than those reported before, following a similar extraction procedure (259.4 and $381 \mathrm{mg} \mathrm{kg}^{-1} \mathrm{dw}$ in bark and wood, respectively) [15]. These differences may arise from the variability caused by geographic origin or edaphoclimatic conditions. Regarding leaves extract, only 22,23-dihydrospinasterol was detected, however at a considerable high content, namely $635.7 \mathrm{mg} \mathrm{kg}^{-1} \mathrm{dw}$. As far as we know, this is the first and only sterol identified in A. dealbata leaves.

Spinasterol has been reported to show various biological properties, including anticarcinogenic, anti-inflammatory, antitumor, antiulcerogenic activities, and antinociceptive effects [19,21,27-30].

\subsubsection{Monoglycerides}

Specific monoglycerides were found in all morphological parts of A. dealbata. Bark extract showed the highest percentage of monoglycerides corresponding to $10.1 \%$ of the total content of identified lipophilic compounds, while leaves and wood extracts showed relatively low amounts $(0.2 \%$ and $1.9 \%$ of the total content of identified compounds). Further, 1-monodocasanoin and 1 -monotetracosanoin were the major monoglycerides found in the bark, representing $149.5 \mathrm{mg} \mathrm{kg}^{-1} \mathrm{dw}$ 
and $538.7 \mathrm{mg} \mathrm{kg}^{-1} \mathrm{dw}$, respectively, and 1-monohexadecanoin was the only monoglyceride found in all extracts. With the exception of 1-monotetracosanoin, previously reported as constituent of A. dealbata bark [17], all other monoglycerides found were identified here for the first time in the different morphological parts of $A$. dealbata.

\subsubsection{Aromatic Compounds}

Several aromatic compounds were identified in A. dealbata bark, wood and leaves (Table 1), with contents ranging between $26.9 \mathrm{mg} \mathrm{kg}^{-1} \mathrm{dw}$ in wood and $112.0 \mathrm{mg} \mathrm{kg}^{-1} \mathrm{dw}$ in leaves. Tyrosol was the dominant aromatic compound observed in leaves extract $\left(48.5 \mathrm{mg} \mathrm{kg}^{-1} \mathrm{dw}\right)$, accounting for $43.3 \%$ of the total aromatic compounds content. Other abundant aromatic compounds were verified in leaves lipophilic extract, namely vanillic and p-coumaric acids (12.4 and $19.8 \mathrm{mg} \mathrm{kg}^{-1} \mathrm{dw}$, respectively). Vanillin was the major aromatic compound $\left(6.8 \mathrm{mg} \mathrm{kg}^{-1} \mathrm{dw}\right)$ of wood lipophilic extract while syringic acid was the most abundant aromatic compound observed in the bark lipophilic extract $\left(7.8 \mathrm{mg} \mathrm{kg}^{-1} \mathrm{dw}\right)$. To the best of our knowledge, all these aromatic compounds are reported here for the first time as components of $A$. dealbata, with exception of syringic and p-coumaric acids that were already described in the literature as constituents of a mixture of aerial parts (wood, bark, and leaves) of A. dealbata [31].

\subsubsection{Other Components}

Finally, other compounds were also identified in high amounts in bark and leaves lipophilic extracts, such as glycerol (20.2 $\mathrm{mg} \mathrm{kg}^{-1} \mathrm{dw}$ in bark and $339.7 \mathrm{mg} \mathrm{kg}^{-1} \mathrm{dw}$ in leaves) and $\alpha$-tocopherol (46.1 $\mathrm{mg} \mathrm{kg}^{-1} \mathrm{dw}$ in bark and $1936.1 \mathrm{mg} \mathrm{kg}^{-1} \mathrm{dw}$ in leaves).

\subsection{Cytotoxity Evaluation of A. dealbata Lipophilic Extracts}

In order to evaluate the safety of lipophilic extracts from bark, wood and leaves of A. dealbata, their cytotoxicity was evaluated by the MTT assay, in cell lines representative of different tissues and organs (brain, innate immune system, skin, lung and liver), namely non-differentiated and differentiated neuronal cells (N2A), microglia (BV-2), macrophages (Raw 264.7), fibroblasts (NIH/3T3), keratinocytes (HaCaT), lung cells (A549), and hepatocytes (HepG2). Regarding non-differentiated neuronal cells (Figure $3 \mathrm{~A}$ ), after $24 \mathrm{~h}$ treatment with the lipophilic extracts, all tested concentrations of leaves extracts were devoid of toxicity, and bark and wood extracts did not exhibit cytotoxicity at doses bellow $50 \mu \mathrm{g} \mathrm{mL}^{-1}$ and $6.3 \mu \mathrm{g} \mathrm{mL} \mathrm{m}^{-1}$, respectively. In differentiated neuronal cells (Figure 3B), an absence of toxicity was observed after $24 \mathrm{~h}$ treatment with the lipophilic extracts at concentrations bellow $50 \mu \mathrm{g} \mathrm{mL}^{-1}$ for leaves and for bark, and $6.3 \mu \mathrm{g} \mathrm{mL}^{-1}$ for wood. In the case of microglia cells, which are the brain-resident immune cells (Figure 3C), non-toxic effects of the lipophilic extracts were observed at $24 \mathrm{~h}$ for concentrations bellow $6.3 \mu \mathrm{g} \mathrm{mL} \mathrm{m}^{-1}$ for leaves and for wood and $3.2 \mu \mathrm{g} \mathrm{mL} \mathrm{m}^{-1}$ for bark. In macrophages (Figure 3D), which are cells of the peripheral immune system, no significant toxicity was observed for all tested concentrations of wood extracts and non-toxic effects were detected $24 \mathrm{~h}$ after cells exposure to the leaves and bark lipophilic extracts at concentrations bellow $6.3 \mu \mathrm{g} \mathrm{mL}^{-1}$ and $25 \mu \mathrm{g} \mathrm{mL}{ }^{-1}$, respectively. Lipophilic extracts of A. dealbata were also tested in skin cells: fibroblasts and keratinocytes, representative of the dermis and epidermis, respectively. In fibroblasts (Figure 3E), absence of toxicity was found after 24-h incubation with these extracts at concentrations bellow $50 \mu \mathrm{g} \mathrm{mL} L^{-1}$ and $12.5 \mu \mathrm{g} \mathrm{mL}^{-1}$ for leaves and for wood, respectively, while no significant toxicity was observed for bark extract at any tested dose. In the case of keratinocytes (Figure 3F), lipophilic extracts induced significant toxicity in concentrations above $25 \mu \mathrm{g} \mathrm{mL} \mathrm{m}^{-1}$ for leaves, $6.3 \mu \mathrm{g} \mathrm{mL} \mathrm{m}^{-1}$ for bark and $12.5 \mu \mathrm{g} \mathrm{mL}^{-1}$ for wood, after $24 \mathrm{~h}$ treatment. In lung cells (Figure 3G), non-toxic effects of the lipophilic extracts were observed at $24 \mathrm{~h}$ for concentrations bellow $25 \mu \mathrm{g} \mathrm{mL}{ }^{-1}$ for leaves, $6.3 \mu \mathrm{g} \mathrm{mL}^{-1}$ for bark, and $3.2 \mu \mathrm{g} \mathrm{mL}^{-1}$ for wood. Finally, lipophilic extracts were shown to be safe in hepatocytes (Figure $3 \mathrm{H}$ ), which are the main liver cells. Indeed, after $24 \mathrm{~h}$ of incubation, significant toxicity of wood extracts was detected only for concentrations above $50 \mu \mathrm{g} \mathrm{mL} \mathrm{m}^{-1}$. 
A-Non-differentiated neurons

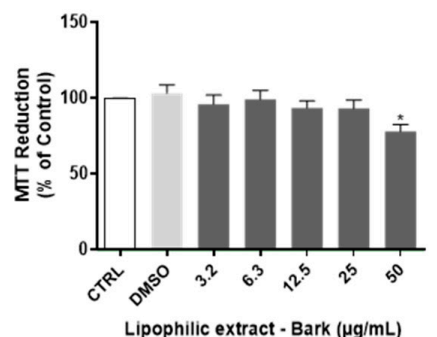

Lipophilic extract - Bark ( $\mu \mathrm{g} / \mathrm{mL})$
B -Differentiated neurons

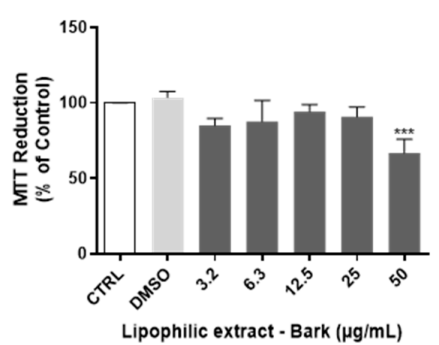

C-Microglia

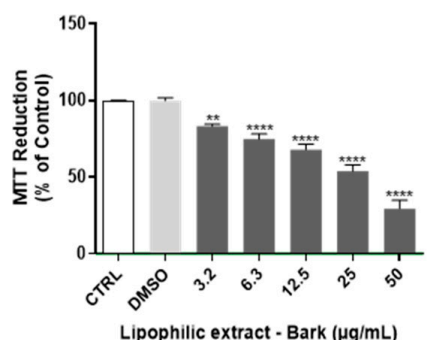

D-Macrophages
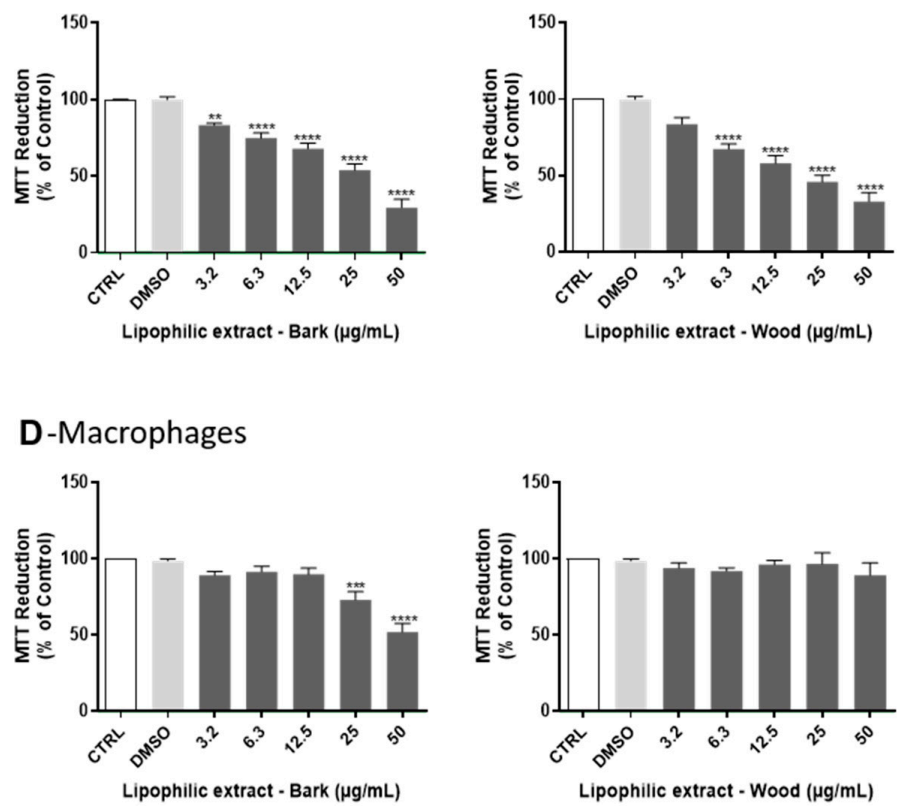

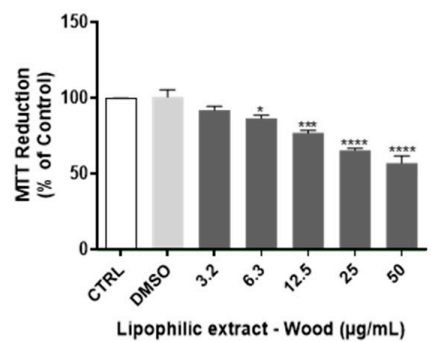

Lipophilic extract - Wood $(\mu \mathrm{g} / \mathrm{mL})$
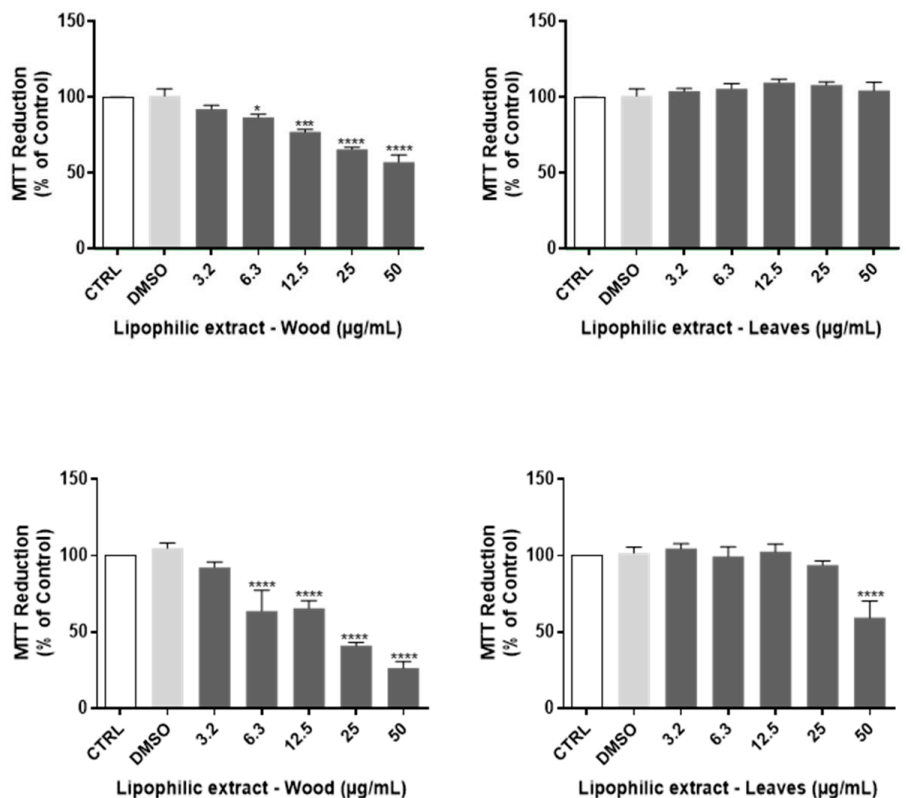

Lipophilic extract - Leaves $(\mu \mathrm{g} / \mathrm{mL})$
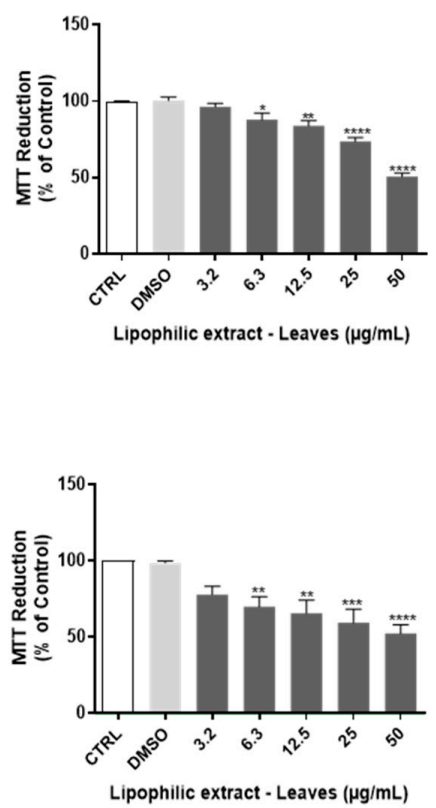

Figure 3. Cont. 


\section{E-Fibroblasts}
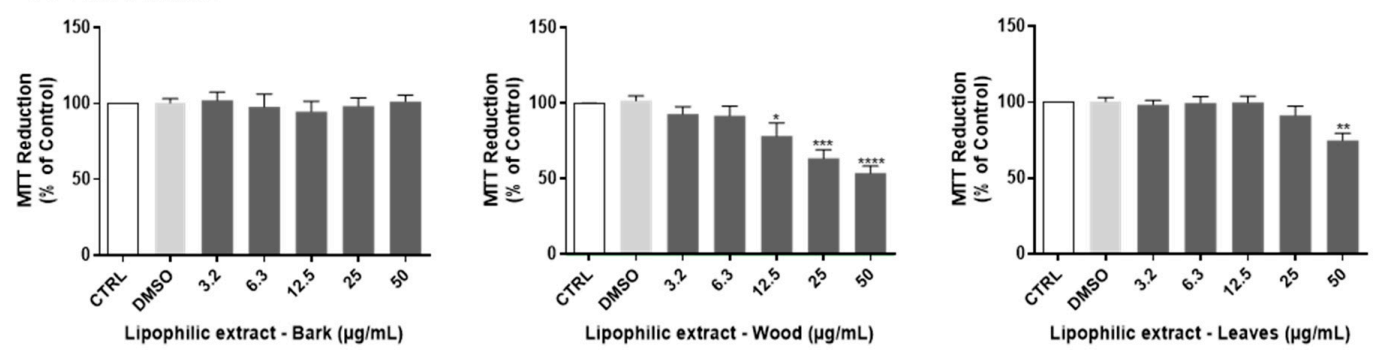

\section{F-Keratinocytes}
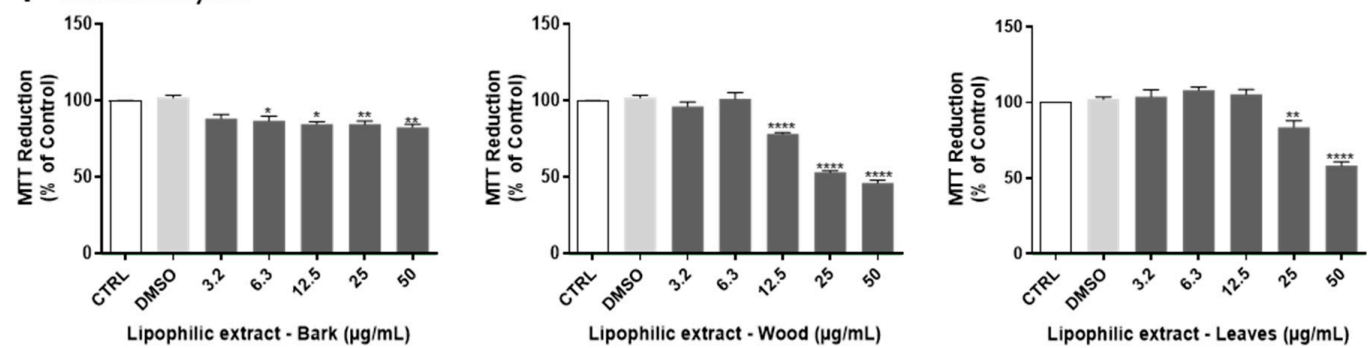

\section{G -Lung cells}
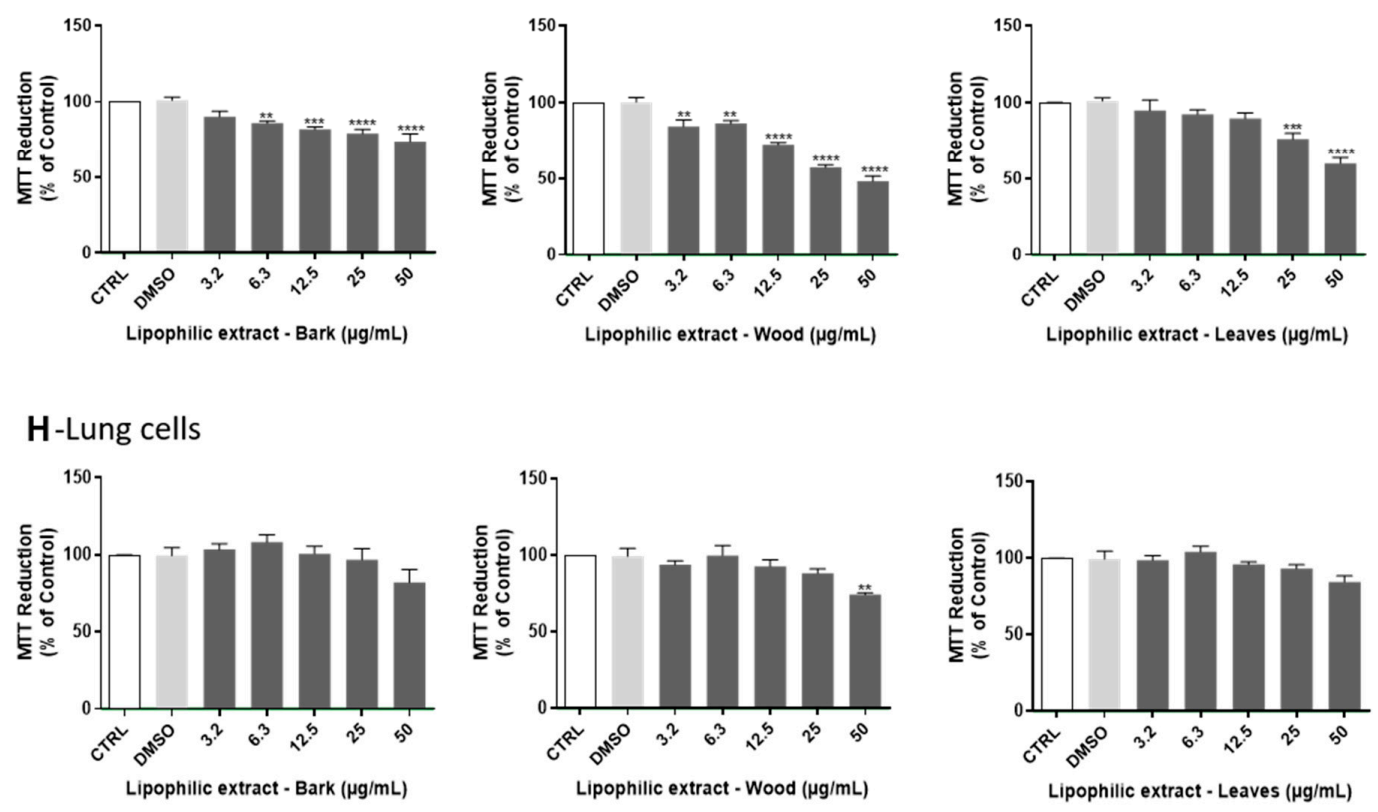

Figure 3. Effect of lipophilic extracts from A. dealbata on non-differentiated (A) and differentiated (B) neuronal N2A, microglia BV-2 (C), macrophages Raw 264.7 (D), fibroblasts NIH/3T3 (E), keratinocytes HaCaT (F), lung A549 (G) and liver hepatocyte HepG2 (H) cells viability. Cells were treated for $24 \mathrm{~h}$ at $37^{\circ} \mathrm{C}$ with concentrations of $0-50 \mu \mathrm{g} \mathrm{mL}^{-1}$ of lipophilic extracts obtained from bark, wood and leaves of $A$. dealbata and then viability was evaluated by the MTT assay. The results expressed as percentage $(\%)$ of control represent the mean \pm SEM of at least 3 independent experiments performed in triplicate. Statistical analysis was made by one-way analysis of variance (ANOVA) followed by Dunnett's multiple comparison test. ${ }^{*} p<0.05,{ }^{* *} p<0.01$, ${ }^{* * *} p<0.001,{ }^{* * * *} p<0.0001$ significantly different compared to control.

For the first time, a cytotoxicity screening of lipophilic extracts obtained from bark, wood and leaves of $A$. dealbata was performed in several mammalian cell lines representing brain, immune system, skin, lung and liver cells, unveiling its safe doses. The results obtained with the lipophilic extracts from leaves and bark are very promising regarding its future incorporation in oral or topic 
pharmaceutical formulations, since there is a lack of toxicity in cells of the liver, namely hepatocytes (HepG2), cells of the epidermis, keratinocytes (HaCaT), and the dermis, fibroblasts (NIH/3T3). In fact, Acacia is used in several cosmetic products, which are applied to different parts of the body, however the available data in the literature is considered insufficient to support the safety of the Acacia-derived cosmetics [32]. The absence of leaves extracts' toxicity towards epithelial alveolar cells supports their potential administration by inhalation. These extracts also displayed low toxicity in non-differentiated and differentiated neuronal cells, and although the pharmacological and medicinal properties of A. dealbata have not been studied yet, different species of Acacia are used for the treatment of convulsions and dizziness [33]. Additionally, the wood lipophilic extract did not exhibit cytotoxicity on macrophages for all the concentrations tested, suggesting that these extracts are not deleterious to the innate immune system. These findings encourage the in-depth evaluation of the bioactive effects of A. dealbata lipophilic extracts, as well as the signaling pathways and molecular targets modulated by the extracts. In fact, the anti-inflammatory activity of wood extracts from other Acacia species have been reported, and is believed to be due to the antioxidant properties, although no direct associations have been made yet [34]. This study highlights the safe bioactive doses of A. dealbata lipophilic extracts emphasizing its therapeutic value that should be more extensively investigated for future applications in the pharmaceutical/nutraceutical industry.

\section{Materials and Methods}

\subsection{Reagents}

Dichloromethane (p.a., $\geq 99 \%$ purity) was supplied by Fisher Scientific (Thermo Fisher Scientific, Waltham, Massachusetts, USA). Pyridine (p.a., $\geq 99.5 \%$ purity), N,O-bis(trimethylsilyl)trifluroacetamide (99\% purity), trimethylchlorosilane (99\% purity), tetracosane (99\% purity), hexadecanoic acid ( $\geq 99 \%$ purity), nonadecan-1-ol (99\% purity), syringic acid (99\% purity), vanillin (99\% purity) and stigmasterol (95\% purity) were supplied by Sigma Chemical Co (Madrid, Spain). Betulonic acid (95\% purity) was purchased from Chemos $\mathrm{GmbH}$ (Regenstauf, Germany).

Dulbecco's Modified Eagle's Medium (DMEM), RPMI-1640 Medium, sodium bicarbonate, sodium pyruvate, non-essential amino acid derivatives, L-glutamine, glucose, phenol red, trypsin-EDTA solution, 3-(4,5-dimethylthiazol-2-yl)-2,5-diphenyltetrazolium bromide (MTT), retinoic acid and dimethyl sulfoxide (DMSO) were supplied by Sigma-Aldrich (Lisbon, Portugal). Fetal bovine serum (FBS), penicillin, and streptomycin were purchased from Gibco (Carlsbad, CA, USA).

\subsection{Sample Collection}

Bark, wood, and leaves samples, representative of harvesting biomass residues, were sampled from a 8-year-old A. dealbata tree, in September 2018, randomly selected from a property of "The Navigator Company", Quinta Rei (GPS coordinates $\left.41^{\circ} 12^{\prime} 50^{\prime \prime} \mathrm{N}, 8^{\circ} 29^{\prime} 34^{\prime \prime} \mathrm{W}\right)$, region of Porto/Valongo, Portugal. Samples were air dried until a constant weight was achieved and grounded in order to select the fraction with a granulometry lower than $1 / 2 \mathrm{~mm}$ prior to extraction.

\subsection{Characterization of Lipophilic Extracts}

\subsubsection{Lipophilic Compounds Extraction}

Three ground samples (nearly $10 \mathrm{~g}$ ) of each fraction (bark, wood and leaves) of A. dealbata tree were Soxhlet extracted during $8 \mathrm{~h}$ with dichloromethane (DCM), a fairly selective solvent to recover lipophilics from biomass $[15,35]$. The solvent was evaporated to dryness, the extracts were weighed, and the results are expressed as a percentage of dry weight $(\mathrm{dw})$ biomass. 


\subsubsection{GC-MS Analysis}

Previous to GC-MS analysis, $20 \mathrm{mg}$ samples of each dried extract were dissolved in $250 \mu \mathrm{L}$ of pyridine containing $0.6 \mathrm{mg}$ of tetracosane (internal standard), and then $250 \mu \mathrm{L}$ of N,O-bis(trimethylsilyl)trifluoroacetamide and $50 \mu \mathrm{L}$ of trimethylchlorosilane were added and the mixture at $70{ }^{\circ} \mathrm{C}$ for $30 \mathrm{~min}$. By adding these last two reagents, the hydroxyl and carboxyl groups of the components of the extracts were converted into trimethylsilyl (TMS) ethers and esters, respectively $[15,36]$.

The derivatized extracts were analyzed by GC-MS using a Trace Gas Chromatograph (2000 series) equipped with a Thermo Scientific DSQ II mass spectrometer (Waltham, Massachusetts, USA). Compounds were separated in a DB-1 J\&W capillary column $(30 \mathrm{~m} \times 0.32 \mathrm{~mm}$ inner diameter, $0.25 \mu \mathrm{m}$ film thickness, Santa Clara, California, USA), using helium as the carrier gas $\left(35 \mathrm{~cm} \mathrm{~s}^{-1}\right)$. The temperature program was as follows: initial temperature, $80^{\circ} \mathrm{C}$ for $5 \mathrm{~min}$; temperature rate, $4{ }^{\circ} \mathrm{C}$ $\mathrm{min}^{-1}$ up to $260{ }^{\circ} \mathrm{C}$; temperature rate, $2^{\circ} \mathrm{C} \mathrm{min}^{-1}$ up to $285^{\circ} \mathrm{C}$ which was kept for $8 \mathrm{~min}$. The injector and the transfer-line temperatures were, respectively $250^{\circ} \mathrm{C}$ and $290^{\circ} \mathrm{C}$, while the split ratio was 1:33. The mass spectrometer was operated in the electron impact mode with energy of $70 \mathrm{eV}$, and the data were collected at a rate of $1 \mathrm{scan} \mathrm{s}^{-1}$ over a range of $m / z 33-700$. The ion source was maintained at $250^{\circ} \mathrm{C}$ [37].

Compounds were identified by comparing their mass spectra (MS) with a mass spectral library (Wiley-NIST Mass Spectral Library, 2014), by comparing their MS fragmentation profiles with literature data $[15,17,37]$ and, in some cases confirmed based on the characteristic retention times under the same experimental conditions [36-38] and/or by injection of standards.

For semi-quantitative analysis, GC-MS calibration was performed with pure reference standards, representative of the main families of lipophilic compounds present in the extracts (hexadecanoic acid, nonadecan-1-ol, betulonic acid, stigmasterol, syringic acid and vanillin), relative to the internal standard (tetracosane). Response factors were determined by averaging six GC-MS runs. Three derivatized extracts were prepared from each morphological part and injected in duplicate. The results presented correspond to the average of the concordant values obtained with a variation of less than $5 \%$ (either between injections of the same aliquots and between triplicate extracts of the same morphological part).

\subsection{Cytotoxicity Evaluation of Lipophilic Extracts}

\subsubsection{Cell Culture}

The mouse neuroblastoma (N2A, from ATCC CCL-131), human keratinocyte (HaCaT, from CLS, Cell Lines Service, Eppelheim, Germany), mouse fibroblast (NIH/3T3, from ATCC CRL-1658) and human lung carcinoma (A549, from ATCC CCL-185) cell lines were cultured with Dulbecco's Modified Eagle's Medium (DMEM) (\#D5648), supplemented with 10\% (v/v) heat-inactivated fetal bovine serum (FBS), $1 \%(v / v)$ antibiotic solution $\left(10,000 \mathrm{U} \mathrm{mL}^{-1}\right.$ penicillin, $10,000 \mu \mathrm{g} \mathrm{mL}^{-1}$ streptomycin), $3.7 \mathrm{~g} \mathrm{~L}^{-1}$ sodium bicarbonate, and $1 \mathrm{mM}$ sodium pyruvate. The N2A cell line culture medium was additionally supplemented with $1 \%(v / v)$ non-essential amino acids. The mouse leukaemic macrophage cell line (Raw 264.7, from ATCC TIB-71) was cultured in DMEM supplemented with 10\% (v/v) non-inactivated FBS, $1 \%(v / v)$ antibiotic solution, $1.5 \mathrm{~g} \mathrm{~L}^{-1}$ sodium bicarbonate and $1 \mathrm{mM}$ sodium pyruvate. The human hepatocellular carcinoma cell line (HepG2, from ATCC HB-8065) was cultured with DMEM (\#D5030), supplemented with $10 \%(v / v)$ heat-inactivated FBS, $1 \%(v / v)$ antibiotic solution, $1.5 \mathrm{~g} \mathrm{~L}^{-1}$ sodium bicarbonate, $1 \mathrm{mM}$ sodium pyruvate, $4 \mathrm{mM}$ L-glutamine, $1 \mathrm{~g} \mathrm{~L}^{-1}$ glucose and phenol red. The mouse microglia cell line (BV-2, from ICLC ATL03001, Interlab Cell Line Collection) was cultured in RPMI-1640 medium (\#R4130) supplemented with 10\% (v/v) heat-inactivated FBS, 1\% $(v / v)$ antibiotic solution and $2 \mathrm{~g} \mathrm{~L}^{-1}$ sodium bicarbonate. Cells were cultured in $75 \mathrm{~cm}^{2}$ flasks and maintained in a humidified $5 \% \mathrm{CO}_{2}-95 \%$ air atmosphere at $37^{\circ} \mathrm{C}$, and the medium was changed every 2-3 days. Cultures were passaged by trypsinization with Trypsin-EDTA solution $1 \mathrm{x}$ when cells reached $70-80 \%$ confluence 
and were sub-cultured over a maximum of ten passages. Raw 264.7 and BV-2 cells were passaged by detaching the cells with a cell scraper.

\subsubsection{Cell Viability Assay}

For the evaluation of cell viability, the 3-(4,5-dimethylthiazol-2-yl)-2,5-diphenyltetrazolium bromide (MTT) reduction assay was performed. RAW 264.7, non-differentiated N2A and HepG2, HaCaT, A549, $\mathrm{NIH} / 3 \mathrm{~T} 3$ and BV-2 cells were seeded in 96-well plates at a density of $9.6 \times 10^{4}, 2.5 \times 10^{4}, 2 \times 10^{4}, 1.6 \times$ $10^{4}, 1 \times 10^{4}$ and $8 \times 10^{3}$ cells/well, respectively, and allowed to adhere for $24 \mathrm{~h}$. For the differentiation of neuronal processes, N2A cells were plated in 24-well plates at a density of $2 \times 10^{4}$ cells/well and $24 \mathrm{~h}$ later were treated with $10 \mu \mathrm{M}$ retinoic acid in DMEM with $1 \%(v / v) \mathrm{FBS}$, during $48 \mathrm{~h}$, with medium refreshed every $24 \mathrm{~h}$. Stock solutions of lipophilic extracts from bark, wood, and leaves of $A$. dealbata were prepared in DMSO and stored at $-20^{\circ} \mathrm{C}$. On the day of experiment, culture medium was replaced by freshly prepared exposure media [DMEM supplemented with $1 \%(v / v)$ FBS or DMEM with $10 \mu \mathrm{M}$ retinoic acid and $1 \%(v / v)$ FBS in the case of differentiated N2A cells and RPMI-1640 medium supplemented with $2 \%(v / v)$ FBS in the case of BV-2 cells]. Each plate also included a solvent control $[0.2 \%(v / v)$ DMSO prepared in exposure medium]. Dose-response curves were obtained incubating the cells with 0-50 $\mu \mathrm{g} \mathrm{mL} \mathrm{m}^{-1}$ lipophilic extracts from bark, wood and leaves of $A$. dealbata for $24 \mathrm{~h}$ at $37^{\circ} \mathrm{C}$. After the incubation period, the medium was removed and a fresh solution of MTT $\left(0.5 \mathrm{mg} \mathrm{L}^{-1}\right)$ prepared in Krebs medium ( $\mathrm{pH}$ 7.4) was added. The different cell lines were incubated with MTT at $37^{\circ} \mathrm{C}$ during 30 min (Raw 264. 7 cells), 1 h (HepG2 cells), 2 h (N2A, A549, and HaCaT cells), 3 h (BV-2), or $4 \mathrm{~h}$ (NIH/3T3 cells). After incubation, the MTT solution was removed and the formed formazan crystals were dissolved in DMSO. The absorbance was measured at $570 \mathrm{~nm}$ in a spectrophotometer (SLT spectra II) after $10 \mathrm{~min}$ shaking. The results were expressed as percentage of the absorbance value obtained in control, which was considered $100 \%$ and were graphically presented as a percentage of cell viability versus the lipophilic extracts concentration $\left(\mu \mathrm{g} \mathrm{mL} \mathrm{m}^{-1}\right)$.

\subsubsection{Statistical Analysis}

The results are presented as the mean \pm standard error of the mean (SEM) of the indicated number of experiments. Normality of the data distribution was assessed by the D'Agostino \& Pearson and Shapiro-Wilk normality tests. Statistical comparisons between groups were performed by one-way analysis of variance (ANOVA) followed by Dunnett's multiple comparison test. Significance was accepted at $p$ values $<0.05$. All statistical calculations were performed using GraphPad Prism software (8.0.2, GraphPad Software Inc., San Diego, CA, USA).

\section{Conclusions}

The present study highlight, for the first time, the detailed chemical composition of the lipophilic fraction of different morphological parts of $A$. dealbata, envisaging their integrated exploitation. The amount and composition of dichloromethane extractives of $A$. dealbata bark, wood and leaves differ significantly. Terpenic compounds represented the major lipophilic family present in bark and leaves extracts, whereas sterols were the dominant components in the wood lipophilic fraction. Leaves extract showed the highest content of lipophilic compounds, with lupenone as the major compound, accounting for $32.5 \%$ of the total lipophilic extract. The bark extract was demonstrated to be rich in long-chain aliphatic alcohols and monoglycerides, while the wood extract presented the highest fatty acids content.

All lipophilic extracts of $A$. dealbata exhibited none or low cytotoxicity at the tested doses in different mammalian cell lines representing brain, immune system, skin, lung, and liver cells, highlighting the potential of these fractions to be further exploited for oral or topic pharmaceutical applications.

The present study thus represents a valuable contribution to promote the economic exploitation of this forest by-product through in-depth knowledge of its chemical composition and safety. These findings encourage the evaluation of the bioactivity of non-toxic doses of these lipophilic extracts 
of $A$. dealbata in order to obtain scientific support for their application in the nutraceutical industry. Additionally, uniformization of procedures to characterize these fractions are an important issue to make possible the comparison between biomass from different geographical origins. Future studies concerning the search for alternative extraction methodologies and solvents, such as supercritical carbon dioxide extraction or extraction with deep eutectic solvents are also crucial to allow the exploitation of this natural resource.

Author Contributions: Conceptualization, C.M.F.P., S.A.O.S. and A.J.D.S.; Formal analysis, C.S.D.O. and J.R.; Investigation, C.S.D.O.; Methodology, C.S.D.O., P.M. and J.R.; Supervision, M.T.C., C.M.F.P., A.M.S.S., S.A.O.S. and A.J.D.S.; Writing—original draft, C.S.D.O. and P.M.; Writing-review \& editing, M.T.C., C.M.F.P., A.M.S.S., S.A.O.S. and A.J.D.S. All authors have read and agreed to the published version of the manuscript.

Funding: This work was carried out under the Project inpactus-innovative products and technologies from eucalyptus, Project N. 21874 funded by Portugal 2020 through European Regional Development Fund (ERDF) in the frame of COMPETE $2020 \mathrm{n}^{\circ}$ 246/AXIS II/2017. The authors thank FCT/MEC for the financial support to CICECO-Aveiro Institute of Materials (UIDB/50011/2020 \& UIDP/50011/2020), LAQV-REQUIMTE (UIDB/50006/2020), and CNC.IBILI Consortia (UIDB/04539/2020), and when appropriate the co-financing support by FEDER, under the PT2020 Partnership Agreement. Sónia A. O. Santos and Judite Resende thank the project "AgroForWealth: Biorefining of agricultural and forest by-products and wastes: integrated strategic for valorization of resources towards society wealth and sustainability" (CENTRO-01-0145-FEDER-000001), for the contract and research grant, respectively.

Conflicts of Interest: The authors declare no conflict of interest. The funders had no role in the design of the study; in the collection, analyses, or interpretation of data; in the writing of the manuscript, or in the decision to publish the results.

\section{References}

1. Lorenzo, P.; Palomera-Pérez, A.; Reigosa, M.J.; González, L. Allelopathic interference of invasive Acacia dealbata Link on the physiological parameters of native understory species. Plant Ecol. 2011, 212, 403-412. [CrossRef]

2. Sheppard, A.W.; Shaw, R.H.; Sforza, R. Top 20 environmental weeds for classical biological control in Europe: a review of opportunities, regulations and other barriers to adoption. Weed Res. 2006, 46, 93-117. [CrossRef]

3. Lorenzo, P.; González, L.; Reigosa, M.J. The genus Acacia as invader: the characteristic case of Acacia dealbata Link in Europe. Ann. For. Sci. 2010, 67, 101. [CrossRef]

4. Aguilera, N.; Becerra, J.; Villaseñor-Parada, C.; Lorenzo, P.; González, L.; Hernández, V. Effects and identification of chemical compounds released from the invasive Acacia dealbata Link. Chem. Ecol. 2015, 31, 479-493. [CrossRef]

5. WorldWideWattle Species Gallery. Acacia dealbata Link. Available online: http://worldwidewattle.com/ speciesgallery/species-intro.php?id=17858 (accessed on 5 January 2020).

6. Santos, A.J.A.; Anjos, O.M.S.; Simões, R.M.S. Papermaking potential of Acacia dealbata and Acacia melanoxylon. Appita. J. 2006, 59, 58-64.

7. CABI Acacia dealbata. In: Invasive Species Compendium. Available online: https://www.cabi.org/isc/ datasheet/2207\#37C102CF-ECB0-4B32-B37E-3B3AC4ACA344 (accessed on 10 January 2020).

8. Pereira, F.B.M.; Domingues, F.M.J.; Silva, A.M.S. Triterpenes from Acacia dealbata. Nat. Prod. Lett. 1996, 8, 97-103. [CrossRef]

9. Silva, E.; Fernandes, S.; Bacelar, E.; Sampaio, A. Antimicrobial activity of aqueous, ethanolic and methanolic leaf extracts from Acacia spp. and Eucalyptus nicholii. African J. Tradit. Complement. Altern. Med. 2016, 13, 130-134. [CrossRef]

10. Gouws, A.J.; Shackleton, C.M. Abundance and correlates of the Acacia dealbata invasion in the northern Eastern Cape, South Africa. For. Ecol. Manage. 2019, 432, 455-466. [CrossRef]

11. Ngorima, A.; Shackleton, C.M. Livelihood benefits and costs from an invasive alien tree (Acacia dealbata) to rural communities in the Eastern Cape, South Africa. J. Environ. Manage. 2019, 229, 158-165. [CrossRef]

12. Rodolphe, P.; Katharina, B.; Meierhenrich, U.J.; Elise, C.; Georges, F.; Nicolas, B. Chemical composition of french mimosa absolute oil. J. Agric. Food Chem. 2010, 58, 1844-1849. [CrossRef]

13. Yáñez, R.; Romaní, A.; Garrote, G.; Alonso, J.L.; Parajó, J.C. Processing of Acacia dealbata in aqueous media: First step of a wood biorefinery. Ind. Eng. Chem. Res. 2009, 48, 6618-6626. [CrossRef] 
14. Nunes, L.J.R.; Meireles, C.I.R.; Pinto Gomes, C.J.; Almeida Ribeiro, N.M.C. Historical development of the portuguese forest: The introduction of invasive species. Forests 2019, 10, 974. [CrossRef]

15. Freire, C.S.R.; Coelho, D.S.C.; Santos, N.M.; Silvestre, A.J.D.; Pascoal Neto, C. Identification of $\Delta^{7}$ phytosterols and phytosteryl glucosides in the wood and bark of several Acacia species. Lipids 2005, 40, 317-322. [CrossRef] [PubMed]

16. Pinto, P.C.R.; Oliveira, C.; Costa, C.A.; Gaspar, A.; Faria, T.; Ataíde, J.; Rodrigues, A.E. Kraft delignification of energy crops in view of pulp production and lignin valorization. Ind. Crops Prod. 2015, 71, 153-162. [CrossRef]

17. Freire, C.S.R.; Silvestre, A.J.D.; Neto, C.P. Demonstration of long-chain n-alkyl caffeates and $\Delta^{7}$-steryl glucosides in the bark of Acacia species by gas chromatography-mass spectrometry. Phytochem. Anal. 2007, 18, 151-156. [CrossRef] [PubMed]

18. Xu, F.; Huang, X.; Wu, H.; Wang, X. Beneficial health effects of lupenone triterpene: A review. Biomed. Pharmacother. 2018, 103, 198-203. [CrossRef]

19. Borges, F.R.M.; Silva, M.D.; Córdova, M.M.; Schambach, T.R.; Pizzolatti, M.G.; Santos, A.R.S. Anti-inflammatory action of hydroalcoholic extract, dichloromethane fraction and steroid $\alpha$-spinasterol from Polygala sabulosa in LPS-induced peritonitis in mice. J. Ethnopharmacol. 2014, 151, 144-150. [CrossRef]

20. Meneses-Sagrero, S.E.; Navarro-Navarro, M.; Ruiz-Bustos, E.; Del-Toro-Sánchez, C.L.; Jiménez-Estrada, M.; Robles-Zepeda, R.E. Antiproliferative activity of spinasterol isolated of Stegnosperma halimifolium (Benth, 1844). Saudi Pharm. J. 2017, 25, 1137-1143. [CrossRef]

21. Villaseñor, I.M.; Domingo, A.P. Anticarcinogenicity potential of spinasterol isolated from squash flowers. Teratog. Carcinog. Mutagen. 2000, 20, 99-105. [CrossRef]

22. El Kharrassi, Y.; Samadi, M.; Lopez, T.; Nury, T.; El Kebbaj, R.; Andreoletti, P.; El Hajj, H.I.; Vamecq, J.; Moustaid, K.; Latruffe, N.; et al. Biological activities of schottenol and spinasterol, two natural phytosterols present in argan oil and in cactus pear seed oil, on murine miroglial BV2 cells. Biochem. Biophys. Res. Commun. 2014, 446, 798-804. [CrossRef]

23. Vijayasekhar, V.E.; Prasad, M.S.; Joshi, D.S.D.S.; Narendra, K.; Satya, A.K.; Rao, K.R.S.S. Evaluation of phytochemicals and in vitro pharmacological activity of Acacia sinuata plant leaves. Int. J. Pharm. Sci. Res. 2016, 7, 2423-2434. [CrossRef]

24. Cordeiro, N.; Freitas, N.; Faria, M.; Gouveia, M. Ipomoea batatas (L.) Lam.: A rich source of lipophilic phytochemicals. J. Agric. Food Chem. 2013, 61, 12380-12384. [CrossRef]

25. Chen, Y.-F.; Ching, C.; Wu, T.-S.; Wu, C.-R.; Hsieh, W.-T.; Tsai, H.-Y. Balanophora spicata and lupeol acetate possess antinociceptive and anti-inflammatory activities in vivo and in vitro. Evid. Based Complement. Altern. Med. 2012, 2012, 1-10. [CrossRef]

26. Lucetti, D.L.; Lucetti, E.C.P.; Bandeira, M.A.M.; Veras, H.N.H.; Silva, A.H.; Leal, L.K.A.M.; Lopes, A.A.; Alves, V.C.C.; Silva, G.S.; Brito, G.A.; et al. Anti-inflammatory effects and possible mechanism of action of lupeol acetate isolated from Himatanthus drasticus (Mart). Plumel. J. Inflamm. 2010, 7, 60. [CrossRef] [PubMed]

27. Jeon, G.-C.; Park, M.-S.; Yoon, D.-Y.; Shin, C.-H.; Sin, H.-S.; Um, S.-J. Antitumor activity of spinasterol isolated from Pueraria roots. Exp. Mol. Med. 2005, 37, 111-120. [CrossRef] [PubMed]

28. Klein, L.C.; Gandolfi, R.B.; Santin, J.R.; Lemos, M.; Filho, V.C.; De Andrade, S.F. Antiulcerogenic activity of extract, fractions, and some compounds obtained from Polygala cyparissias St. Hillaire \& Moquin (Polygalaceae). Naunyn. Schmiedebergs. Arch. Pharmacol. 2010, 381, 121-126. [CrossRef]

29. Ardenghi, J.V.; Pretto, J.B.; Souza, M.M.; Junior, A.C.; Soldi, C.; Pizzolatti, M.G.; Meotti, F.C.; Moura, J.; d'Ávila; Santos, A.R.S. Antinociceptive properties of coumarins, steroid and dihydrostyryl-2-pyrones from Polygala sabulosa (Polygalaceae) in mice. J. Pharm. Pharmacol. 2006, 58, 107-112. [CrossRef]

30. Jeong, G.-S.; Li, B.; Lee, D.-S.; Kim, K.H.; Lee, I.K.; Lee, K.R.; Kim, Y.-C. Cytoprotective and anti-inflammatory effects of spinasterol via the induction of heme oxygenase-1 in murine hippocampal and microglial cell lines. Int. Immunopharmacol. 2010, 10, 1587-1594. [CrossRef]

31. Luís, A.; Gil, N.; Amaral, M.E.; Duarte, A.P. Antioxidant activities of extracts from Acacia melanoxylon, Acacia dealbata and Olea europaea and alkaloids estimation. Int. J. Pharm. Pharm. Sci. 2012, 4, 225-231. 
32. Johnson, W. Final report of the safety assessment of Acacia Catechu gum, Acacia Concinna fruit extract, Acacia dealbata leaf extract, Acacia dealbata leaf wax, Acacia decurrens extract, Acacia farnesiana extract, Acacia farnesiana flower wax, Acacia farnesiana gum, Acacia senegal extract, Acacia senegal gum, and Acacia Senegal gum extract. Int. J. Toxicol. 2005, 24, 75-118. [CrossRef]

33. Mohammad Alharbi, W.D.; Azmat, A. Anticonvulsant and neuroprotective effects of the Acacia tortilis growing in KSA. Pak. J. Pharm. Sci. 2015, 28, 531-534.

34. Stohs, S.J.; Bagchi, D. Antioxidant, anti-inflammatory, and phemoprotective properties of Acacia catechu heartwood extracts. Phyther. Res. 2015, 29, 818-824. [CrossRef] [PubMed]

35. Freire, C.S.R.; Silvestre, A.J.D.; Neto, C.P. Identification of new hydroxy fatty acids and ferulic acid esters in the wood of Eucalyptus globulus. Holzforschung 2002, 56, 143-149. [CrossRef]

36. Patinha, D.J.S.; Domingues, R.M.A.; Villaverde, J.J.; Silva, A.M.S.; Silva, C.M.; Freire, C.S.R.; Neto, C.P.; Silvestre, A.J.D. Lipophilic extractives from the bark of Eucalyptus grandis $x$ globulus, a rich source of methyl morolate: Selective extraction with supercritical $\mathrm{CO}_{2}$. Ind. Crops Prod. 2013, 43, 340-348. [CrossRef]

37. Ramos, P.A.B.; Moreirinha, C.; Santos, S.A.O.; Almeida, A.; Freire, C.S.R.; Silva, A.M.S.; Silvestre, A.J.D. Valorisation of bark lipophilic fractions from three Portuguese Salix species: A systematic study of the chemical composition and inhibitory activity on Escherichia coli. Ind. Crop. Prod. 2019, 132, 245-252. [CrossRef]

38. Ramos, P.A.B.; Guerra, A.R.; Guerreiro, O.; Freire, C.S.R.; Silva, A.M.S.; Duarte, M.F.; Silvestre, A.J.D. Lipophilic extracts of Cynara cardunculus L. var. altilis (DC): A source of valuable bioactive terpenic compounds. J. Agric. Food Chem. 2013, 61, 8420-8429. [CrossRef]

(C) 2020 by the authors. Licensee MDPI, Basel, Switzerland. This article is an open access article distributed under the terms and conditions of the Creative Commons Attribution (CC BY) license (http://creativecommons.org/licenses/by/4.0/). 